\title{
EFFECT OF OVERWEIGHT ON GASTROESOPHAGEAL REFLUX DISEASE IN ADULTS: A META-ANALYSIS
}

\author{
Fitria Wulandari, Bhisma Murti \\ Masters Program in Public Health, Universitas Sebelas Maret
}

\begin{abstract}
Background Epidemiological data have demonstrated that overweight and obesity is an important risk factor for the development of gastroesophageal reflux disease (GERD). A commonly suggested pathogenetic pathway is the increased abdominal pressure which relaxes the lower esophageal sphincter, thus exposing the esophageal mucosal to gastric content. Apart from the mechanical pressure, visceral fat is metabolically active and it has been strongly associated with serum levels of adipocytokines, which may play a role in GERD. The study objective was to investigate the effect of overweight on GERD in adults.

Subjects and Method: A systematic review was conducted using the Google Scholar, PubMed, and SpringerLink databases and the following search criteria: "GERD OR Gastroesophageal reflux" AND overweight AND Obesity AND "adjusted Odds Ratio". The inclusion criteria were full-text, cross-sectional, and reported adjusted Odds Ratio. The systematic review was carried out according to the PRISMA guidelines. Data analyses were performed using RevMan 5.3.

Results: A total of 9 articles from India, North India, South India, Pakistan, Indonesia, China, Tunisia, Nigeria, and Albania were eligible for quantitative metaanalyses. This study showed that overweight increased the risk of GERD in adults $(\mathrm{aOR}=1.81 ; 95 \% \mathrm{CI}=1.32$ to $2.48 ; \mathrm{p}<0.001)$.
\end{abstract}

Conclusion: Overweight increases the risk of GERD in adults.

Keywords: overweight, gastroesophageal reflux disease, adult

\section{Correspondence:}

Fitria Wulandari. Masters Program in Public Health, Universitas Sebelas Maret. Jl. Ir. Sutami 36A, Surakarta 57126, Central Java. Email: fitriawulan14@gmail.com. Mobile: 082169215248. 